AT - TADBIR

\title{
Implikasi Budaya Organisasi Dan Kepemimpinan Terhadap Kinerja Karyawan Pada Bank Bri Karawang
}

\author{
Gian Dirgantara*, Sonny Hersona GW \\ Magister Manajemen, Universitas Singaperbangsa, Karawang \\ e-mail: gian.dirgantara@gmail.com
}

\begin{abstract}
Employee performance is very important in an organization, because the success of an organization is very dependent on the quality and performance of human resources in the organization. Several aspects of employee performance levels are needed and can be determined at the same time, including organizational culture and leadership capabilities. Several previous studies have shown that the role of organizational culture is very important, and it is very likely that it is motivated by leaders in the organization. Banking is one of the industries with a fairly high employee turnover rate. Therefore, this research was conducted in one of the branches of BRI Bank Karawang branch. The purpose of this study was to examine its effect on employee performance, organizational culture and leadership. The research was conducted at Bank BRI Karawang, with a sample of 70 employees. Data was collected using a questionnaire as a research tool. The analysis technique used is multiple linear regression analysis. The results of the analysis show that organizational culture has a positive effect on employee performance, while leadership has an effect on employee performance. However, the results of the influence of leadership show better results than organizational culture.
\end{abstract}

Keywords: banking culture, employee performance, BRI bank, organizational culture, leadership

\begin{abstract}
Abstrak
Kinerja karyawan sangat penting dalam suatu organisasi, karena keberhasilan suatu organisasi sangat bergantung pada kualitas dan kinerja sumber daya manusia dalam organisasi tersebut. Beberapa aspek tingkat kinerja karyawan dibutuhkan dan dapat ditentukan pada saat yang bersamaan, diantaranya adalah budaya organisasi dan kapabilitas kepemimpinan. Beberapa penelitian terdahulu menunjukkan bahwa peran dari budaya organisasi sangat penting, dan sangat mungkin dilatarbelakangi oleh para pemimpin dalam organisas. Perbankan merupakan salah satu industry dengan tingkat turnover karyawan yang cukup tinggi. Oleh karena itu penelitian ini dilakukan di salah satu cabang Bank BRI cabang Karawang. Tujuan dari penelitian ini adalah untuk menguji pengaruhnya terhadap kinerja karyawan, budaya organisasi dan kepemimpinan. Penelitian dilakukan di Bank BRI Karawang, dengan jumlah sampel 70 karyawan. Pengumpulan data dilakukan menggunakan kuesioner sebagai alat penelitian. Teknik analisis yang digunakan adalah analisis regresi linier berganda. Hasil analisis menunjukkan bahwa budaya organisasi berpengaruh positif terhadap kinerja pegawai, sedangkan kepemimpinan berpengaruh terhadap kinerja pegawai.Meskipun demikian, hasil dari pengaruh kepemimpinan menunjukkan hasil yang lebih baik dibandingkan dengan budaya organisasi.
\end{abstract}

Kata Kunci: budaya perbankan, kinerja pegawai, bank BRI, budaya organisasi, kepemimpinan 


\section{PENDAHULUAN}

Kinerja merupakan kondisi yang harus diinformasikan dan diinformasikan kepada pihak tertentu untuk mengetahui tingkat pencapaian hasil organisasi terkait dengan visi yang diimplementasikan oleh organisasi, serta memahami dampak positif dan negatif dari kebijakan operasional yang diambil. Adapun indikator penilaian kinerja di perusahaan diantaranya integritas, komitmen, disiplin, kerja sama, dan kepemimpinan.

Dengan informasi tentang kinerja perusahaan, langkah-langkah yang diperlukan dapat diambil, seperti mengoreksi kebijakan, mengklarifikasi kegiatan dan tugas utama lembaga, bahan perencanaan, dan menentukan keberhasilan lembaga dalam menentukan suatu ukuran dan masih banyak lagi.

Dalam setiap organisasi dalam perusahaan dan pemerintahan memiliki ciri atau identitas yang unik, artinya setiap organisasi memiliki kepribadiannya masing-masing. Salah satu faktor yang membedakan suatu organisasi dengan organisasi lain adalah budayanya. Budaya organisasi berkaitan dengan bagaimana karyawan menerima nilai-nilai budaya organisasi. Budaya organisasi adalah kemauan, kemampuan, dan kemauan seseorang untuk menyesuaikan perilakunya agar sesuai dengan budaya organisasi, dan sangat berkaitan dengan kemauan, kemampuan, dan kemauan untuk meningkatkan efisiensi kerja.

Menurut Fuad Mas'ud (2004), budaya organisasi adalah suatu sistem makna, nilai, dan kepercayaan yang dimiliki bersama dalam suatu organisasi. Organisasi menjadi acuan tindakan dan menjadikan organisasi saling eksklusif. Bedakan, inilah yang dilakukan Hofstede (1993) disebutkan dalam Fuad. Indikator budaya Mas.'ud (2004) adalah profesionalisme, keterbukaan, keteraturan karyawan, ketidakpercayaan rekan kerja dan integrasi karyawan.

Budaya organisasi mewakili norma perilaku yang harus diikuti oleh anggota organisasi (termasuk anggota dalam hierarki organisasi). Bagi organisasi yang masih didominasi oleh pendiri, budaya organisasi akan menjadi sarana penyampaian harapan pendiri kepada anggota organisasi lainnya.

Permasalahan yang berkaitan dengan sumber daya manusia dalam suatu organisasi memerlukan perhatian, karena betapapun kompleksnya teknologi yang digunakan dalam organisasi dan seberapa besar modal yang dimiliki organisasi tersebut, anggota atau karyawan dalam organisasi pada akhirnya adalah orang-orang yang menjalankan teknologi tersebut (Kammerhoff, et al., 2019).

Hal ini menunjukkan bahwa tanpa dukungan karyawan yang berkualitas tidak dapat mencapai kesuksesan organisasi. Kontribusi karyawan terhadap organisasi akan menentukan kemajuan atau kemunduran organisasi. Salah satu upaya untuk mencapai tujuan organisasi adalah dengan menuntut karyawan untuk bekerja sesuai dengan standar dan norma organisasi. Jika kinerja sumber daya manusia baik, maka tujuan, visi dan misi organisasi juga akan baik, begitu pula sebaliknya.

Biasanya kinerja karyawan akan dipengaruhi oleh budaya organisasi dan faktor kepemimpinan organisasi. Melalui manajemen sumber daya manusia, Anda dapat memandu kinerja dengan lebih efektif, terutama dalam hal tujuan organisasi. Kepemimpinan merupakan salah satu faktor yang sering menimbulkan kontroversi, karena pemerintah dan masyarakat semakin sadar bahwa kunci pencapaian tujuan di tingkat nasional, daerah atau lokal bergantung pada instansi, instansi, perusahaan, lembaga dan lain-lain yang terkemuka, sehingga Jelaskan bahwa sukses / gagalnya suatu organisasi ditentukan oleh kepemimpinan, dan pemimpin bertanggung jawab atas pelaksanaan semua tugas (Meng \& Berger, 
2019).

Pemimpin adalah orang yang memiliki motivasi untuk memimpin dan mengendalikan organisasi. Pemimpin yang efektif akan secara sukarela berusaha untuk mencapai tujuan dan target yang lebih tinggi dengan menetapkan standar kinerja yang tinggi untuk diri mereka sendiri. Pemimpin yang efektif memiliki sifat bersemangat, sama seperti segala sesuatu yang menantang dan masalah serta masalah yang tidak terpecahkan yang muncul di lingkungan organisasi. Seorang pemimpin yang efektif akan berusaha mengubah keinginan seseorang untuk melakukan sesuatu dengan menunjukkan arah yang harus diambil dan membimbing anggota kelompok untuk menyelesaikan hasil kerja kelompok. Menurut Susilo Martoyo (2000), pemimpin adalah seseorang yang memiliki kemampuan memimpin dan dapat mempengaruhi perilaku orang lain atau kelompok. Menurut Martoyo (2000), indikator kepemimpinan meliputi keterampilan analitis, keterampilan komunikasi, keberanian, kemampuan mendengar, dan ketegasan.

Dalam sebuah organisasi, hubungan antara pemimpin dan anggota organisasi memiliki dua pengaruh, artinya terdapat interaksi dan reaksi timbal balik antar orang-orang dalam organisasi tersebut. Pemimpin memiliki tugas atau tujuan yang ingin dia capai, dan pemimpin akan berusaha untuk berpindah tugas dengan mendorong pengikutnya untuk mencapai tingkat pencapaian yang memuaskan. Pegawai Bank BRI Karawang harus mencapai kinerja yang tinggi dengan meningkatkan budaya organisasi dan membentuk jiwa kepemimpinan.

Namun menurut pengamatan penulis, budaya organisasi yang dibentuk oleh BRI Bank Karawang masih kurang baik, terlihat bahwa kurangnya keterbukaan, kepercayaan pada rekan kerja, integritas pegawai yang rendah, dan kurangnya disiplin pegawai masih disebabkan oleh mereka yang jangan masuk kantor tepat waktu, karyawan, dan ketika pemimpin mangkir, karyawan cenderung mengabaikan pekerjaan

Mengenai kinerja pegawai, hal ini menunjukkan bahwa kinerja pegawai bukanlah pilihan terbaik untuk mencapai kinerja pegawai, masih diperlukan peningkatan kejujuran pegawai, tanggung jawab pegawai terhadap pekerjaan, kepatuhan pegawai terhadap peraturan perundangundangan yang berlaku, dan kerjasama antar pegawai. Karyawan serta jiwa kepemimpinan (Awadh \& Alyahya, 2013).

Dari pernyataan di atas penelitian ini bertujuan untuk mengetahui peran dari budaya organisasi dan kepemimpinan di lingkungan Bank BRI cabang Karawang.

\section{TINJAUAN PUSTAKA}

Dalam penelitian ini budaya organisasi dan kepemimpinan merupakan variabel bebas, sedangkan kinerja pegawai sebagai variabel terikat. Sebagai variabel independen, variabel budaya organisasi memiliki indikator sebagai berikut: profesionalisme, keterbukaan, keteraturan karyawan, kecurigaan rekan kerja dan integrasi karyawan. Sebagai variabel bebas, variabel kepemimpinan memiliki indikator: keterampilan analitis, keterampilan komunikasi, keberanian, keterampilan menyimak, dan kepercayaan diri. Sebagai variabel terikat, variabel kinerja pegawai memiliki indikator: integritas, komitmen, disiplin, kerjasama dan kepemimpinan. Berdasarkan uraian di atas, penulis menjabarkan kerangka kerja sebagai berikut:

\section{Kinerja Pegawai}

Penelitian tentang kinerja memberikan definisi terhadap kinerja pegawai sebagai berikut. Menurut Ilham (2018), kinerja adalah hasil kerja baik secara kualitas maupun kuantitas yang dicapai oleh seorang 
pegawai dalam melaksanakan tugasnya sesuai dengan tanggung jawab yang diberikan kepadanya. Kinerja pegawai adalah prestasi kerja atau hasil kerja (output) baik kualitas maupun kuantitas yang dicapai pegawai per satu periode waktu dalam melaksanakan tugas pekerjaannya sesuai dengan tanggung jawab yang diberikan kepadanya. Menurut Na-Nan \& Chaiprasit (2018), indikator kinerja dibagi menjadi tiga, antara lain kualitas pekerjaan, kuantitas pekerjaan, dan waktu kerja.

\section{Budaya Organisasi}

Budaya organisasi adalah nilai atau pola dasar yang diterima oleh suatu organisasi untuk bertindak dan memecahkan masalah, membentuk karyawan yang mampu beradaptasi dengan lingkungan dan menyatukan anggota organisasi (Robbins, 2006). Budaya organisasi adalah pola dasar yang diterima oleh organisasi untuk bertindak dan memecahkan masalah, membentuk karyawan yang mampu beradaptasi dengan lingkungan dan menyatukan anggota organisasi. Ini harus diajarkan kepada anggota termasuk anggota baru sebagai cara yang benar untuk menilai, berpikir dan merasakan masalah yang dihadapi (Manggis et al., 2018). Pemaksaan suatu budaya dapat menimbulkan ketidaksesuaian antara karyawan dengan organisasi sehingga mempengaruhi kondisi psikologis karyawan yang merasa tidak nyaman dalam bekerja sama (Piantara et al., 2021).

Budaya dan kinerja dianggap saling terkait satu sama lain oleh manajemen yang kuat. Sementara hubungan yang kuat antara praktik manajemen, kinerja dan manajemen budaya menunjukkan pembentukan budaya berlangsung secara efektif (Awadh \& Alyahya, 2013).

Budaya organisasi ditemukan tidak berpengaruh signifikan terhadap kinerja karyawan. Hal ini menunjukkan bahwa kantor tidak dapat mengelola perubahan organisasi dan budaya organisasi untuk kinerja staf yang lebih baik. Resistensi staf terhadap perubahan dan merupakan proses jangka panjang dan membutuhkan waktu yang lebih lama bagi staf untuk melakukan penyesuaian terhadap perubahan diyakini di antara alasan tidak signifikannya perubahan organisasi dan budaya organisasi terhadap kinerja staf di Pekerjaan Umum dan Penataan Ruang Dinas, Kabupaten Pidie, Provinsi Aceh, Indonesia (Rozanna et al., 2019).

\section{Kepemimpinan}

Teori kepemimpinan dan teori organisasi menjadi instrumen penting dalam menjalankan aktivitas dalam organisasi (Stogdill, 1974). Kepemimpinan dalam organisasi perlu dimiliki oleh seluruh anggota internal organisasi, apapun visi dan misinya. Oleh karena itu, suatu organisasi atau perusahaan membutuhkan sosok pemimpin yang dapat menjadi contoh bagi anggota internal organisasi lainnya. Kepemimpinan adalah suatu proses untuk mempengaruhi kegiatan yang ada, terutama untuk memimpin organisasi dalam kelompok untuk mencapai tujuan yang telah ditetapkan sejak awal (Mitchell \& Scott, 1987). Bagi Pigors, dalam bukunya "Leadership and Domination," kepemimpinan adalah proses yang mendorong yang mengontrol kegunaan manusia dalam mengejar tujuan bersama, melalui interaksi yang berhasil dari berbagai perbedaan individu (Pigors, 1933).

Beberapa peneliti (Kammerhoff, et al., 2019; Eliyana et al ., 2019; Meng \& Berger, 2019) menyatakan bahwa terdapat korelasi yang kuat antara peran kepemimpinan terhadap kepuasan kerja dengan kinerja karyawan. Chiniara dan Bentein (2016) berfokus pada bagaimana hubungan antara kepemimpinan dan kinerja individu dimediasi antara kompetensi dan kepuasan 
berdasarkan teori Self Determination dan OCB (Organizational Citizenship Behavior). Selain itu organisasi perkotaan membutuhkan kepemimpinan, budaya organisasi dan motivasi kerja yang kuat untuk mendukungnya. peningkatan kinerja (Lolowang et al., 2019).

Berdasarkan kerangka konsep di atas, model hipotesis disajikan pada Gambar 1, diikuti asumsi sebagai berikut:
H1: Diduga budaya organisasi berpengaruh positif dan signifikan terhadap kinerja pegawai Bank BRI Karawang.

H2: Diduga kepemimpinan berpengaruh positif dan signifikan terhadap kinerja pegawai pada bank BRI Karawang.

H3: Diduga budaya organisasi dan kepemimpinan berpengaruh positif dan signifikan terhadap kinerja pegawai Bank BRI Karawang.

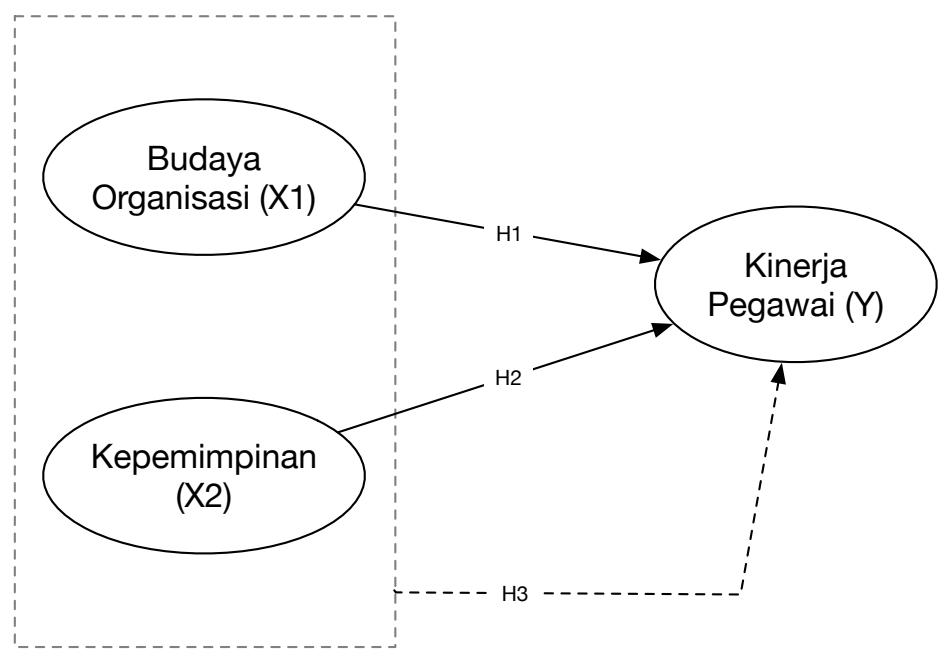

Gambar 1. Keragka Hipotesis

\section{METODE PENELITIAN}

\section{Jenis Penelitian}

Metode yang digunakan dalam penelitian ini adalah metode kuantitaif dengan pendekatan eksplanatori. Berkaitan dengan hal tersebut, peneliti menggabungkan metode penelitian dengan metode survei. Berdasarkan pemahaman di atas, dapat disimpulkan bahwa metode survei deskriptif sesuai untuk penelitian yang sedang penulis lakukan, yaitu untuk memperoleh gambaran tentang pengaruh budaya organisasi dan kepemimpinan terhadap kinerja pegawai.

\section{Populasi dan Sampel}

Populasi dalam penelitian ini adalah karyawan Bank BRI Karawang yang berjumlah 70 orang. Jumlah anggota sampel biasanya diwakili oleh jumlah sampel.
Jumlah sampel yang mewakili suatu populasi diharapkan sama dengan jumlah penduduk itu sendiri atau jumlah anggota sensus (Sugiyono, 2010). Oleh karena itu, apabila populasinya 70 orang, dan hasil penelitiannya akan diterapkan dengan benar pada 70 orang tersebut maka jumlah sampel yang diambil akan sama dengan populasinya yaitu 70 orang.

\section{Metode Pengumpulan Data}

Pengumpulan data dapat dilakukan dari dua sumber, yaitu sumber primer dan sekunder. Satu jenis. Sumber utama adalah sumber data yang memberikan data langsung ke pengumpul data. b. Sumber sekunder adalah sumber yang tidak secara langsung memberikan data ke pengumpul data melalui orang atau dokumen lain. Mengingat 
kebutuhan untuk memperoleh data penelitian termasuk data asli dan data pembantu, maka metode atau teknik pengumpulan data berikut dapat digunakan: 1. Penelitian pustaka 2. Penelitian Lapangan (Field Research).

\section{Skala pengukuran dan Analisis Data}

Dalam studi lapangan, skala pengukuran digunakan. Pada dasarnya pengukuran adalah kegiatan mengukur variabel yang diteliti. Pengukuran variabel dilakukan dengan menggunakan instrumen penelitian skala besar. Data yang diperoleh dari hasil kuesioner yang disebarkan di Bank BRI Karawang diberi skor yang telah ditentukan dan dianalisis menggunakan uji statistik. Gunakan program komputer Windows Statistics Service Solution Products (SPSS) untuk memproses analisis statistik.

\section{HASIL DAN PEMBAHASAN}

\section{Hasil}

Koefisien korelasi (R) variabel budaya organisasi (X1) sebesar 0,885 yang menunjukkan bahwa koefisien korelasi variabel budaya organisasi mempunyai korelasi positif karena lebih besar dari 0,5. Variabel kepemimpinan (X2) sebesar 0,877 menunjukkan bahwa koefisien korelasi variabel kepemimpinan memiliki korelasi positif, karena lebih besar dari 0,5. Hal tersebut dapat dilihat pada Tabel 1. Nilai koefisien determinasi dapat diuraikan sebagai berikut :

1. Pengaruh budaya organisasi (X1) terhadap kinerja pegawai (Y) didasarkan pada data penelitian yang telah melalui pengolahan asosiasi sederhana, dan (r) diperoleh hubungan antara budaya organisasi dan kinerja pegawai $(0,885)$. Dengan kata lain peningkatan budaya organisasi akan mengarah pada peningkatan kinerja pegawai, sehingga level yang tersirat tergolong sangat kuat, artinya budaya organisasi yang lebih baik akan berdampak pada peningkatan kinerja pegawai dan menentukan level yang tersirat. . Koefisien determinasi (r) 2 dihitung sebagai berikut: $\mathrm{Kd}=\mathrm{r} 2 \times 100 \%=$ (0.885) $2 \times 100 \%=0,783 \times 100 \%=78,3 \%$ Dari hasil perhitungan diperoleh nilai koefisien determinasi (r) 2 sebesar 0,783 yang artinya $78,3 \%$ kinerja pegawai ditentukan oleh budaya organisasi, dan sisanya dipengaruhi oleh $21,7 \%$ faktor lain.

\section{Pengaruh Kepemimpinan (X2) Terhadap} Kinerja Pegawai (Y) Berdasarkan data penelitian setelah pengolahan korelasi sederhana diperoleh hasil ungkapan makna antara kepemimpinan dan kinerja pegawai adalah (r) 0,877. Dengan kata lain dengan peningkatan kemampuan kepemimpinan maka kinerja pegawai juga akan meningkat yang artinya tingkat pengaruhnya sangat kuat, artinya semakin baik kemampuan kepemimpinan maka kinerja pegawai akan semakin tinggi. Sedangkan koefisien determinasi (r) 2 dapat dihitung sebagai berikut: $\mathrm{Kd}=\mathrm{r} 2 \times 100 \%=(0.877) 2 \times 100 \%$ $=0,769 \times 100 \%=76,9 \%$ Dari hasil perhitungan diperoleh nilai koefisien determinasi (r) 2 sebesar 0,769 yang artinya 76,9\% kinerja karyawan ditentukan oleh pimpinan, dan sisanya dipengaruhi oleh $23,1 \%$ faktor lain.

3. Pengaruh budaya organisasi (X1) dan kepemimpinan (X2) terhadap kinerja karyawan (Y) Proses analisis dilakukan dengan menggunakan komputer melalui program SPSS for Windows sebagai alat bantu.

Hasil analisis dapat diuraikan sebagai berikut: Melalui proses analisis ini diperoleh nilai korelasi (r) yaitu sebesar 0,893 . Dengan demikian koefisien 
determinasi (r2) sebesar 0,798 yang artinya $79,8 \%$ kinerja karyawan ditentukan oleh budaya organisasi dan kepemimpinan, dan sisanya dipengaruhi oleh $21,2 \%$ faktor lain. Pada tahap selanjutnya hasil pengujian dapat disajikan dalam tabel berikut:

Dari hasil analisis data pengolahan komputer berdasarkan perhitungan Windows SPSS diperoleh persamaan regresi berganda, seperti gambar dibawah ini:

$$
\begin{gathered}
\mathrm{Y}=\mathrm{a}+\mathrm{b} 1 \mathrm{X} 1+\mathrm{b} 2 \mathrm{X} 2 \\
=5.979+0,473 \mathrm{X} 1+0,383 \mathrm{X} 2
\end{gathered}
$$

Dari rumus di atas berarti: Satu jenis. Dengan asumsi variabel budaya organisasi konstan maka setiap kenaikan 1 poin pada variabel budaya organisasi berarti terjadi peningkatan sebesar 0,473 poin pada variabel kinerja karyawan. b. Dengan asumsi variabel kepemimpinan konstan maka setiap kenaikan 1 poin pada variabel kepemimpinan akan berdampak pada peningkatan 0,383 poin pada variabel kinerja pegawai. Secara terperinci hasil pengujian hipotesis yang diajukan dalam penelitian ini adalah dijelaskan sebagai berikut:

1. Hipotesis pertama adalah untuk mengetahui pengaruh budaya organisasi terhadap kinerja pegawai pada bank BRI Karawang. Keputusan yang diambil adalah sebagai berikut: Ho: b1 $=0$; Budaya organisasi Bank BRI Karawang tidak berpengaruh terhadap kinerja pegawai. $\mathrm{H} 1$ : b1 $\neq 0$; budaya organisasi bank BRI Karawang berpengaruh terhadap kinerja pegawai. Jika thitung $>$ ttabel, maka Ho ditolak dan H1 diterima Dengan bantuan hasil uji-t olahan komputer, berdasarkan perhitungan SPSS for Windows diperoleh koefisien $t$ hitung b1 sebagai berikut:
Berdasarkan perhitungan di atas, Nilai $\mathrm{t}$ hitung variabel budaya organisasi (X1) sebesar 15,659, dan t tabel dengan derajat kebebasan 68 sebesar 1,995 $(0,05)$. Oleh karena itu thitung $(15,659)>$ ttabel $(1,995)$, maka jelas Ho ditolak dan H1 diterima. Hal ini menunjukkan bahwa budaya organisasi mempunyai pengaruh yang positif dan penting bagi kinerja pegawai Bank BRI Karawang.

2. Hipotesis kedua adalah untuk mengetahui pengaruh kepemimpinan terhadap kinerja pegawai pada bank BRI Karawang. Keputusan yang diambil adalah sebagai berikut: Ho: b2 = 0; Bank BRI Karawang tidak memiliki peran kepemimpinan dalam kinerja pegawai. $\mathrm{H} 1$ : b2 $\neq 0$; kinerja pegawai Bank BRI Karawang berpengaruh terhadap kepemimpinan. Dasar pengambilan keputusan adalah membandingkan $\mathrm{t}$ hitung dengan $\mathrm{t}$ tabel sebagai berikut: jika $\mathrm{t}>\mathrm{t}$ tabel, maka Ho ditolak dan $\mathrm{H} 1$ diterima.

Berdasarkan perhitungan di atas, Nilai thitung variabel kepemimpinan (X2) sebesar 15,041, dan $t$ tabel dengan $t(0,05)$ derajat kebebasan sebesar 1,995. Oleh karena itu thitung $(15,041)>$ ttabel $(1,995)$, maka jelas Ho ditolak dan $\mathrm{H} 1$ diterima. Hal ini menunjukkan bahwa kepemimpinan mempunyai pengaruh yang positif dan penting terhadap kinerja pegawai bank BRI Karawang.

3. Hipotesis ketiga untuk mengetahui pengaruh budaya organisasi dan kepemimpinan terhadap kinerja pegawai BRI Karawang. Keputusan yang diambil adalah sebagai berikut: $\mathrm{H} 0$ : $\mathrm{b} 1=\mathrm{b} 2=0$; Budaya organisasi dan kepemimpinan Bank BRI Karawang tidak berpengaruh terhadap kinerja pegawai. $\mathrm{H} 1: \mathrm{b} 1 \neq 0$ atau $\mathrm{b} 1 \neq 0$, yang berdampak pada kinerja pegawai bank 
BRI Karawang. Jika Fhitung > Ftabel maka Ho ditolak dan $\mathrm{H} 1$ diterima.

Berdasarkan perhitungan SPSS jendela di atas diperoleh nilai Fhitung sebesar 132,124, dan nilai Fhitung dari Ftabel dengan derajat kebebasan $0,05 \%$ adalah $\mathrm{nl}$ $=2$, dan nilai Fhitung $\mathrm{n}=68$ adalah 3,13 .
Dengan demikian thitung $(132,124)>$ ttabel $(3,13)$, maka jelas Ho ditolak dan $\mathrm{H} 1$ diterima. Hal ini menunjukkan bahwa budaya organisasi dan kepemimpinan berpengaruh positif dan signifikan terhadap kinerja pegawai Bank BRI Karawang.

Tabel 1. Uji Korelasi Sederhana

\begin{tabular}{|c|c|c|c|c|}
\hline & & $\times 1$ & $\times 2$ & Y \\
\hline \multirow[t]{3}{*}{$\mathrm{X1}$} & Pearson Correlation & 1 & $.947^{* *}$ & $.885^{\circ}$ \\
\hline & Sig. (1-tailed) & & .000 & .000 \\
\hline & $\mathrm{N}$ & 70 & 70 & 70 \\
\hline \multirow[t]{3}{*}{$\overline{x 2}$} & Pearson Correlation & $.947^{* *}$ & 1 & $.877^{*}$ \\
\hline & Sig. (1-tailed) & .000 & & .000 \\
\hline & $\mathrm{N}$ & 70 & 70 & 70 \\
\hline \multirow[t]{3}{*}{ Y } & Pearson Correlation & $.885^{*}$ & $.877^{* *}$ & 1 \\
\hline & Sig. (1-tailed) & .000 & .000 & \\
\hline & $\mathrm{N}$ & 70 & 70 & 70 \\
\hline
\end{tabular}

Tabel 2. Hasil Pengujian Hipotesis

\begin{tabular}{|l|l|l|l|l|}
\hline & Koefisien Beta & Std. Error & \multicolumn{1}{|c|}{ Uji T } & Keterangan \\
\hline Koefisien & 5.979 & 2.88 & $2.07^{*}$ & Signifikan \\
\hline $\begin{array}{l}\text { Budaya } \\
\text { Organisasi }\end{array}$ & 0.794 & 0.051 & $15.659^{*}$ & Signifikan \\
\hline Kepemimpinan & 0.888 & 0.059 & $15.041^{*}$ & Signifikan \\
\hline $\mathbf{R}$ & 0.893 & & & \\
\hline $\mathbf{R}^{\mathbf{2}}$ & 0.798 & & & \\
\hline $\mathbf{F}$ & $132.124^{*}$ & & & \\
\hline
\end{tabular}

Dependen: Kinerja Pegawai

* Signifikan pada taraf 0.01

\section{Pembahasan}

Pengaruh budaya organisasi dan kepemimpinan terhadap kinerja pegawai Bank Karawang menunjukkan bahwa budaya organisasi dan keterampilan kepemimpinan secara bersama-sama dapat meningkatkan kinerja pegawai di Bank BRI Karawang. Oleh karena Fhitung $>$ Ftabel, sehingga hipotesis Ho: ditolak dan H1: diterima. Dari hasil perhitungan statistik Fhitung $>$ Ftabel terlihat bahwa budaya organisasi dan faktor kepemimpinan secara bersama-sama berpengaruh positif terhadap kinerja pegawai Bank BRI Karawang, dengan kata lain semakin baik budaya organisasi maka semakin baik pula kepemimpinannya. Kinerja karyawan Bank BRI Karawang.

Makna budaya organisasi Bank BRI Karawang menunjukkan bahwa budaya organisasi mempunyai pengaruh yang positif dan penting bagi kinerja pegawai Bank BRI Karawang. Oleh karena itu dapat dikatakan bahwa budaya organisasi mempunyai pengaruh yang positif dan penting bagi kinerja pegawai Bank BRI Karawang, dengan kata lain semakin baik budaya organisasi maka semakin baik pula kinerja pegawai Bank BRI Karawang. Budaya 
organisasi Bank BRI Karawang menunjukkan volatilitas yang tinggi. Persentase skor budaya organisasi terendah adalah 34 dan tertinggi 83. Hasil uji hipotesis membuktikan bahwa budaya organisasi berpengaruh positif dan signifikan terhadap kinerja pegawai Bank BRI Karawang, dan pengaruh tersebut menunjukkan jumlah yang paling baik. Hal ini sejalan dengan Awadh \& Alyahya, (2013) yang menyatakan budaya dan kinerja dianggap saling terkait satu sama lain oleh manajemen yang kuat. Sementara hubungan yang kuat antara praktik manajemen, kinerja dan manajemen budaya menunjukkan pembentukan budaya berlangsung secara efektif. Ketika organisasi mampu mengelola perubahan organisasi dan budaya organisasi untuk kinerja staf yang lebih baik, hal ini akan ditunjukkan dengan rendahnya resistensi staf terhadap perubahan dan merupakan proses jangka panjang dan membutuhkan waktu yang lebih cepat bagi staf untuk melakukan penyesuaian terhadap perubahan diyakini di antara alasan tidak signifikannya perubahan organisasi dan budaya organisasi kinerja.

Pengaruh Pimpinan terhadap Kinerja Pegawai Bank BRI Karawang Pengaruh kepemimpinan terhadap kinerja pegawai bank BRI Karawang menunjukkan bahwa kepemimpinan berpengaruh positif dan signifikan terhadap kinerja pegawai Bank BRI Karawang. Oleh karena itu dapat dikatakan bahwa kepemimpinan mempunyai arti yang positif dan penting bagi kinerja pegawai Bank BRI Karawang, dengan kata lain semakin baik kepemimpinannya maka semakin baik pula kinerja pegawai Bank BRI Karawang.

Hasil uji hipotesis membuktikan bahwa kepemimpinan berpengaruh positif dan signifikan terhadap kinerja karyawan, dan pengaruh tersebut menunjukkan jumlah yang paling baik dibandingkan dengan pengaruh oleh budaya organisasi. Kepemimpinan dalam organisasi modern dimasa kini memang membutuhkan figur pemimpin yang kuat (Lolowang et al., 2019). Lebih lanjut Chiniara dan Bentein (2016) menambahkan fokus para pimpinan pada hubungan antara kepemimpinan dan kinerja individu harus berdasarkan kepuasan dengan memahami konsep teori Self Determination dan OCB (Organizational Citizenship Behavior).

\section{KESIMPULAN DAN SARAN}

Kesimpulan

Pengaruh budaya organisasi dan kepemimpinan terhadap kinerja pegawai Bank Karawang menunjukkan bahwa budaya organisasi dan keterampilan kepemimpinan secara bersama-sama dapat meningkatkan kinerja pegawai di Bank BRI Karawang.

Oleh karena itu dapat dikatakan bahwa budaya organisasi mempunyai pengaruh yang positif dan penting bagi kinerja pegawai Bank BRI Karawang, dengan kata lain semakin baik budaya organisasi maka semakin baik pula kinerja pegawai Bank BRI Karawang.

Hasil dari penelitian ini menunjukkan bahwa ketika organisasi mampu mengelola perubahan organisasi dan budaya organisasi untuk kinerja staf yang lebih baik, hal ini akan ditunjukkan dengan rendahnya resistensi staf terhadap perubahan dan merupakan proses jangka panjang dan membutuhkan waktu yang lebih cepat bagi staf untuk melakukan penyesuaian terhadap perubahan diyakini di antara alasan tidak signifikannya perubahan organisasi dan budaya organisasi kinerja. Pengaruh Pimpinan terhadap Kinerja Pegawai Bank BRI Karawang Pengaruh kepemimpinan terhadap kinerja pegawai bank BRI Karawang menunjukkan bahwa kepemimpinan berpengaruh positif dan signifikan terhadap kinerja pegawai Bank BRI Karawang. 


\section{Saran}

Meskipun demikian penelitian ini memiliki beberapa kelemahan. Pertama penelitian ini hanya berfokus hanya pada satu cabang. Penelitian di masa mendatang diharapkan mampu mencakup lingkup populasi dan sampel yang lebih luas. Kedua, terdapat kemungkinan moderasi dari variabel demografis seperti masa kerja, latar belakang, dan jabatan. Sehingga penelitian di masa mendatang dapat mempertimbangkan posisi dari variabel tersebut. Pada akhirnya dari penelitian ini diharapkan dapat memberikan sumbangan masukan terhadap manajemen perusahaan dalam mengelola lingkungan organisasi terutama beberapa hal terkait dengan budaya organisasi dan kepemimpinan.

\section{DAFTAR PUSTAKA}

Arep, Ishak dan Hendri Tanjung. 2003. Manajemen Sumber Daya Manusia. Universitas Trisakti: Jakarta.

Awadh, A. M., \& Alyahya, M. S. (2013). Impact of organizational culture on employee performance. International review of management and business research, 2(1), 168.

Chiniara, M., \& Bentein, K. (2016). Linking servant leadership to individual performance: Differentiating the mediating role of autonomy, competence and relatedness need satisfaction. Leadership Quarterly, 27(1), 124-141. https://doi.org/10.1016/j.leaqua.2015.08. 004

Eliyana, A., Ma'arif, S., \& Muzakki. (2019). Job satisfaction and organizational commitment effect in the transformational leadership towards employee performance. European Research on Management and Business Economics, 25(3), 144-150. https://doi.org/10.1016/j.iedeen.2019.05. 001
Free Press. Bernardin, H. John, dan Joyce E.A Russel. 2003. Human resource management (An Experimental Approach International Edition). Mc. Graw-Hill Inc. Singapore.

Ghozali, Imam. 2006. Aplikasi Analisis Multivariate dengan Program SPSS (Edisi Ke 4). Semarang: Badan Penerbit Universitas Diponegoro.

Gibson, J L., Ivanicevic J. M., Donelly, J. H., \& Konopaske, Robert. (2009). Organizations Behevior, Structure, Processes (13th ed). New York: McGraw-Hill.

Handoko, T. Hani. 2000. Manajemen Personalia dan Manajemen Sumber Daya Manusia. BPFE. Yogyakarta.

Ilham, R. (2018). The impact of organizational culture and leadership style on job satisfaction and employee performance. Journal of Advanced Management Science, 6(1), 50-53.

Kammerhoff, J., Lauenstein, O., \& Schutz, A. (2019). Leading toward harmony Different types of conflict mediate how followers' perceptions of transformational leadership are related to job satisfaction and performance. European Management Journal, 37(2), 210-221.

https://doi.org/10.1016/j.emj.2018.06.00 3

Kartono, Kartini. 2008. Pemimpin dan Kepemimpinan, Jakarta: CV. Rajawali Kencana.

Kreitner, Robert \& Kinicki, Angelo, 2005, Organizational Behavior, Mc Graw Hill Companies, Inc. New York 98

Kreitner. Robert, \& Kinicki. Angelo. (2007). Organizational Behavior. 7th ed. McGrawHill Inc. New York.

Lolowang, N. L., Troena, E. A., Djazuli, A., $\&$ Aisjah, S. (2019). The effect of leadership and organizational culture on employee performance that is educated 
by motivation (study on the implementation empowerment programs in Jayapura city). Problems and perspectives in management, (17, Iss. 1), 268-277.

Mahsun, Mohamad. 2006. Pengukuran Kinerja Sektor Publik: Cetakan Pertama Yogyakarta: Penerbit BPFE-Yogyakarta.

Manggis, I. W., Yuesti, A., \& Sapta, I. K. S. (2018). The Effect of Career Development and Organizational Culture to Employee Performance with Motivation of Work as Intervening Variable in Cooperation in Denpasar Village. International Journal of Contemporary Research and Review, 9(07), 20901-20916.

Martoyo, Susilo. 2000. Manajemen Sumber Daya Manusia. Jogjakarta: PT BPFE.

Miftah, Thoha. (2013). Perilaku Organisasi Konsep Dasar Dan Implikasinya. Jakarta: PT. Raja Grafindo Persada.

Mitchell, T. R., \& Scott, W. G. (1987). Leadership failures, the distrusting public, and prospects of the administrative state. Public Administration Review, 47(6), 445-452. https://doi.org/10.2307/975885

Na-Nan, K., Chaiprasit, K., \& Pukkeeree, P. (2018). Factor analysis-validated comprehensive employee job performance scale. International Journal of Quality \& Reliability Management.

Nazir, Moh. 2009. Metode Penelitian. Jakarta: Ghalia Indonesia.

Nitisemito, Alex.S, 2006, Manajemen Personalia: Manajemen sumber Daya Manusia, Edisi Keempat, Ghalia Indonesia, Jakarta.

Pabundu, Tika, 2006, Budaya Organisasi dan Peningkatan Kinerja Perusahaan, Jakarta: Cetakan Pertama, PT Bumi Aksara.

Piantara, S., Hersona, S., Martini, N., \& Suyaman, D. J. (2021). Pengaruh Budaya Organisasi, Motivasi Dan Lingkungan
Kerja Terhadap Kinerja Mitra Dinas Koperasi Dan UKM. At-Tadbir: jurnal ilmiah manajemen, 5(2), 106-119.

Pigors, P. (1933). Leadership and domination among children, 140-157. Houghton Mifflin Company

Rivai, Veithzal dan Ahmad Fawzi. 2005. Performance Appraisal, Sistem yang Tepat untuk Menilai Kinerja Karyawan. Jakarta : RajaGrafindo Persada.

Rivai, Veithzhal, 2005, Manajemen Sumber Daya Manusia untuk Perusahaan: dari Teori Ke Praktek, Penerbit PT. Raja Grafindo Persada, Jakarta.

Robbins, Stephen P, 2003, Perilaku Organisasi, Edisi 9 Jilid 1, Indeks Kelompok Gramedia, Jakarta.

Robbins, Stephen P. dan Timothy A. Judge, 2008, Perilaku Organisasi, Edisi 12 Jilid 1 dan 2, Jakarta: Salemba Empat.

Rozanna, N., Adam, M., \& Majid, M. S. A. (2019). Does job satisfaction mediate the effect of organizational change and organizational culture on employee performance of the Public Works and Spatial Planning Agency. IOSR Journal of Business and Management, 21(1), 4551.

Santoso, Singgih. 2010. Mengolah Data Statistik Secara Profesional. PT. Alex Media Komputindo. Jakarta.

Schein, Edgar, 2005, Organization Culture and Leadership, Jossey Bass, San Fransisco, USA.

Simamora, Henry. 2004. Manajemen Sumber Daya Manusia. Edisi III. STIE YKPN. Yogyakarta.

Singarimbun, Masri dan Sofian Effendi. 2008. Metode Penelitian Survei, Jakarta: LP3ES.

Sondang P. Siagian, 2003. Teori dan Praktek Kepemimpinan, PT. Rineka Cipta Jakarta.

Stogdill, R. M. (1974). Handbook of leadership: A survey of theory and 
research. New York, NY: Free Press.

Sugiyono, Dr. 2010. Metode penelitian Kuantitatif Kualitatif dan R\&D, Penerbit Alfabeta
Wirawan. 2007. Budaya dan iklim organisasi: teori aplikasi dan penelitian, Jakarta: Salemba Empat. 